\title{
Pseudomembranous colitis: An update
}

\author{
Harpreet S Brar MD, Christina M Surawicz MD
}

\begin{abstract}
HS Brar, CM Surawicz. Pseudomembranous colitis: An update. Can J Gastroenterol 2000;14(1):51-56. Clostridium difficile is the most common nosocomial infection of the gastrointestinal tract. Most cases are associated with antibiotic therapy that alters the fecal flora, allowing overgrowth of $\mathrm{C}$ difficile with production of its toxins. Diagnosis is made by detection of the organism or toxin in the stools. A variety of different tests can be used, but none is perfect. A stool culture can be positive in someone without diarrhea, ie, a carrier. While the cytotoxin is the gold standard, it is expensive, and there is a delay before results are available. Thus, many laboratories use the enzyme-linked immunoassay tests to detect toxin of $\mathrm{C}$ difficile because they are a more rapid screen. Depending on the specific test used, they can detect toxin A, toxin B or occasionally both. Sensitivity and specificity rates vary. First line therapy for $\mathrm{C}$ difficile disease should be metronidazole $250 \mathrm{mg}$ qid for 10 days. Vancomycin should be reserved for severe cases where metronidazole has failed or where metronidazole cannot be tolerated or is contraindicated. Recurrent $\mathrm{C}$ difficile disease is a particularly vexing clinical problem. A variety of biotherapeutic approaches have been used. Retreatment with antibiotics is almost always necessary. In addition, the nonpathogenic yeast Saccharomyces boulardii has been showed to be of benefit as an adjunct in preventing further recurrences.
\end{abstract}

Key Words: Clostridium difficile; Enzyme-linked immunoassay; Pseudomembranous colitis

\section{Colite pseudo-membraneuse : une mise à jour}

RÉSUMÉ : Clostridium difficile est l'infection nosocomiale la plus courante du tractus intestinal. La plupart des cas sont associés à une antibiothérapie qui altère la flore intestinale, permettant la prolifération de C. difficile avec libération de toxines. Le diagnostic est posé par dépistage de l'organisme ou de ses toxines dans les selles. On peut utiliser différents tests mais aucun d'entre eux n'est parfait. Une culture des selles peut être positive chez un sujet sans diarrhée, c'est à dire, un sujet porteur. La recherche de cytotoxines constitue le test de référence mais ce dernier est coûteux, et un certain délai est nécessaire pour obtenir les résultats. C'est pourquoi de nombreux laboratoires font appel aux dosages par une technique immuno-enzymatique pour déceler la toxine de C. difficile parce qu'elle constitue une méthode de dépistage plus rapide. Selon le test spécifique utilisé, il est possible de déceler la toxine $\mathrm{A}$, la toxine $\mathrm{B}$ et quelquefois les deux à la fois. Les taux de sensibilité et de spécificité varient. Le traitement de première ligne pour la maladie causée par C. difficile devrait être du métronidazole à raison de $250 \mathrm{mg}$ quatre fois par jour pendant 10 jours. On devrait réserver la vancomycine pour les cas sévères résistants au métronidazole ou en cas d'intolérance ou de contre-indication au métronidazole. La récurrence de la maladie à $\mathrm{C}$. difficile est un problème clinique particulièrement contrariant. Une variété d'approches biothérapeutiques ont été utilisées mais une deuxième antibiothérapie est presque toujours nécessaire. De plus, la levure non pathogène Saccharomyces boulardii s'est révélée bénéfique comme traitement adjuvant pour prévenir d'autres récidives de la maladie.
$\mathrm{C}$ lostridium difficile is the most common nosocomial infection of the gastrointestinal tract. Epidemics have been documented in hospitals as well as in nursing homes and rehabilitation centres (1). The association of $\mathrm{C}$ difficile disease with antibiotic therapy is well recognized, and many newer broad spectrum antibiotics may predispose patients to its acquisition. C difficile can cause diarrhea in previously healthy individuals who are given antibiotics in an outpa- tient setting. This article focuses on the diagnosis and therapy for $\mathrm{C}$ difficile-associated disease, as well as on illness complicated by ileus, toxic megacolon or recurrences.

\section{PATHOGENESIS}

Pseudomembranous colitis (PMC) occurs when changes in fecal flora allow the overgrowth of $\mathrm{C}$ difficile with production of its toxins $\mathrm{A}$ and $\mathrm{B}$. This usually occurs in the setting of an-

This Mini-review was prepared from a presentation made at the 1998 Annual Postgraduate Course of the Americal College of Gastroenterology,

October 10 to 11, 1998, Boston, Massachusetts

Harborview Medical Center, Seattle, Washington, USA

Correspondence: Dr Christina M Surawicz, Harborview Medical Center, Ninth Avenue, Box 359773, Seattle, Washington 98104 , USA.

Telephone 206-731-5917, fax 206-731-5917, e-mail surawicz@u. Washington

Received for publication April 20, 1999. Accepted May 10, 1999 
TABLE 1

Detection of Clostridium difficile toxins

\begin{tabular}{lcc}
\hline Method & Sensitivity & Specificity \\
\hline $\begin{array}{l}\text { Cytopathic effect toxin B } \\
\begin{array}{l}\text { Enzyme-linked immunoassay } \\
\text { toxin A }\end{array}\end{array}$ & Gold standard & Gold standard \\
$\begin{array}{l}\text { Polymerase chain reaction of stool } \\
\text { Pol }\end{array}$ & $85 \%$ & $100 \%$ \\
\hline
\end{tabular}

tibiotic use, when colonization resistance is altered by changes in fecal flora. Colonization resistance is the term coined by Van der Waaij et al (2) in 1971 to describe the protective role of the indigenous enteric flora, preventing colonization by microorganisms that are pathogens or potential pathogens. Anaerobic bacteria appear to be crucial in maintaining colonization resistance. For example, in mice given broad spectrum antibiotics, the fecal flora is altered but is re-established only if anaerobes are given orally. The mechanisms of colonization resistance are not known but are probably multiple, such as the ability of some bacteria to inactivate beta-lactam antibiotics or other antibiotics. Patients who receive tube feeding are also more likely to acquire $\mathrm{C}$ difficile independent of antibiotic use (3).

$\mathrm{C}$ difficile has been identified from various sources in the environment (including spores in the soil and water). In hospitals, the patient with PMC is the most important reservoir. Impaired colonization resistance permits $\mathrm{C}$ difficile spores to germinate in the human gut. Gut mucus may serve as a chemoattractant (4). C difficile has been shown to produce several enzymes that may mediate tissue degradation. Among these, hyaluronidase, chondroitin-4-sulphatase and collagenase have all been studied extensively. In addition, C difficile's toxins, enterotoxin (toxin A) and cytotoxin (toxin B), have been studied. Both toxins produce vascular permeability and hemorrhage, but only toxin A leads to fluid accumulation. However, toxin $B$ is reported to be more harmful to colonic epithelium in vitro (5). Both toxins may catalyze glucosylation of threonine at position 37 on the GTP-binding protein Rho. This may lead to change from F-actin to G-actin in cells, thus accounting for the cell rounding seen in tissue culture (6). In general, strains that produce more toxin and are more adherent are more virulent.

\section{DIAGNOSIS}

Clinical clues: $\mathrm{C}$ difficile-associated diarrhea should be suspected in anyone who develops diarrhea during antibiotic therapy. Diarrhea can even occur up to eight weeks after the end of a course of antibiotics. It is more common after oral antibiotics, and has even been reported as a complication of single dose cephalosporin given preoperatively (7). The diagnosis is made by detection of $\mathrm{C}$ difficile and/or one of its toxins in the stool. Colitis should be suspected when there is fever, abdominal pain and diarrhea with gross or occult blood in the stools (8). White blood cells may be present in the stools but are not a reliable indicator of colitis. They can be absent even when stools are positive for toxins. A recent pro- spective analysis of factors predicting a positive $\mathrm{C}$ difficile toxin in the stool indicated usefulness of the following predictive parameters: cephalosporin use, prolonged hospital stay, onset of diarrhea six or more days after receiving antibiotics, fecal leucocytes in the stool and presence of semiformed stool (6). A study to identify patients with a very low likelihood of $\mathrm{C}$ difficile-associated diarrhea found that patients without a history of antibiotic use or significant diarrhea or abdominal pain were unlikely to have a positive C difficile toxin assay (9).

Stool tests: A good review of diagnostic tests has been published recently by Brazier (10).

C difficile cytotoxin (toxin B): The gold standard in diagnosis is the presence of $\mathrm{C}$ difficile cytotoxin (toxin B) in the stools (Table 1). This is present in $95 \%$ to $100 \%$ of cases of PMC. The test is performed using tissue culture; the test is positive when cells show cytopathic rounding - an effect of the cytotoxin. The test takes at least 24 to $48 \mathrm{~h}$. The test can be falsely negative if the stool specimen has been improperly stored or if toxin levels are too low to be detected. C difficile cytotoxin is degraded at room temperature; therefore, if the stool must be stored, it should be kept refrigerated at $4^{\circ} \mathrm{C}$ until tested. Strains that produce only toxin $\mathrm{A}$ are uncommon but can also explain the false negative toxin. Overall, the specificity is $95 \%$ to $99 \%$ and sensitivity is $70 \%$ to $100 \%$. The cost of toxin is $\$ 36.00$ in laboratories in Seattle, Washington. $\mathrm{C}$ difficile culture: The role of $\mathrm{C}$ difficile culture is controversial because it detects asymptomatic carriers. Certainly there are patients with diarrhea who have $\mathrm{C}$ difficile in the stool but do not have toxin. When their diarrhea responds to therapy that eradicates $\mathrm{C}$ difficile, this entity is called ' $\mathrm{C}$ difficile-positive toxin-negative diarrhea' (11). Obviously it can only be diagnosed with culture. For this reason, $\mathrm{C}$ difficile culture is advocated in cases where diagnosis is uncertain, in evaluating some cases of chronic diarrhea or when empirical therapy has failed. As with the cytotoxin, there is a 24 to $48 \mathrm{~h}$ delay in receiving results. The cost of culture is $\$ 24.50$ in our hospital's microbiology laboratory.

Enzyme-linked immunoassay $\mathrm{C}$ difficile toxin assays: The first enzyme-linked immunoassay test for detection of $\mathrm{C}$ difficile toxins in stools was developed by Yolken et al (12) in 1981. Many clinical laboratories use one of several enzyme-linked immunoassays to detect toxins A, B or both. Reports of sensitivity of $85 \%$ and specificity of $100 \%$ have been reported (13-16). These tests are used as a rapid screen; a false negative test does not always exclude disease, and clinical judgement is still important. At the Harborview Medical Centre, Seattle, Washington, the C difficile antigen test used costs $\$ 27.00$.

Latex agglutination test: The latex agglutination assay is a rapid test to detect a $C$ difficile protein. It does not detect the enterotoxin, but rather a protein that can be positive due to other bacteria such as other clostridial strains (17). It is used as initial rapid screen, but results must be interpreted with caution because false positive results may range from $1 \%$ to $30 \%$; sensitivity ranges from $68 \%$ to $90 \%$.

Other stool tests: Molecular methods such as polymerase 
TABLE 2

Antibiotic therapy for Clostridium difficile disease

\begin{tabular}{lccc}
\hline Antibiotic & Dose & Cost for 10-day course (US\$) & Side effects \\
\hline Metronidazole & $250 \mathrm{mg}$ qid & $25-30$ & $\begin{array}{c}\text { Nausea, vomiting, diarrhea, metallic taste, 'antabuse' effect, } \\
\text { peripheral neuropathy (irreversible) }\end{array}$ \\
Vancomycin & $125 \mathrm{mg}$ qid & 300 & Rash (rare) \\
Bacitracin & $25,000 \mathrm{U}$ qid & 150 & Bitter taste \\
Fusidic acid & $0.5-1.5 \mathrm{~g} /$ day & Not Available in United States & \\
Teicoplanin & $100 \mathrm{mg}$ bid & Not available in United States & \\
\hline
\end{tabular}

chain reaction are described in the literature (18) as having a sensitivity of $83 \%$ and a specificity of $100 \%$ when applied to stool. The sensitivity and specificity of $100 \%$ are reported with polymerase chain reaction methods applied to $\mathrm{C}$ difficile cultures (19). However, these methods are limited by cost and general lack of availability outside a research setting. The test may be useful for evaluating epidemics.

Endoscopy: When an immediate diagnosis is necessary, flexible sigmoidoscopy or colonoscopy can be used to visualize the colonic mucosa. Typical pseudomembranes are creamy white or yellow plaques adherent to the mucosa. These are usually seen in the distal colon within the reach of a flexible sigmoidoscope. Occasionally, they can be limited to the right colon ( $10 \%$ to $20 \%$ of cases), so full colonoscopy can be considered in cases where the diagnosis is strongly suspected but the left colon looks normal.

\section{THERAPY FOR C DIFFICILE DISEASE}

Initial therapy: Initial evaluation should assess hydration and severity of illness. The diagnosis rests on stool examination, but because results may not be available for 24 to $48 \mathrm{~h}$, empirical therapy may sometimes be necessary. It is reasonable to treat for $\mathrm{C}$ difficile in anyone who develops diarrhea in the hospital, in some cases of chronic diarrhea, when symptoms worsen or progress, when colitis is present or in anyone who has a history of prior $\mathrm{C}$ difficile infection.

Antibiotics: The two most commonly used antibiotics to treat $\mathrm{C}$ difficile disease are metronidazole and vancomycin (Table 2). The recommended oral doses are metronidazole $250 \mathrm{mg}$ qid or vancomycin 125 to $500 \mathrm{mg}$ qid for 10 days. The lower dose of vancomycin (125 mg qid) is as effective as the higher dose ( $500 \mathrm{mg}$ qid) in mild to moderate disease and is significantly less costly (20). Vancomycin was the first agent used to treat PMC $(21,22)$. Vancomycin is not absorbed from the gastrointestinal tract; thus, side effects are uncommon. Rash has been reported.

Metronidazole is absorbed from the gastrointestinal tract. Side effects include nausea, vomiting, peripheral neuropathy, a metallic taste in the mouth and an 'antabuse-like' effect requiring patients to abstain from drinking alcohol. Although $\mathrm{C}$ difficile resistance is rare, cases of PMC have been reported in association with metronidazole.

Clinical trials indicate that the two drugs are equivalent for the treatment of mild disease (23). Metronidazole should be used as the first line choice for $\mathrm{C}$ difficile disease. Vanco- mycin use must be restricted to lessen the risk of development of vancomycin-resistant organisms such as Enterococci species. In addition, metronidazole is more cost effective. We favour the use of vancomycin when there is no response or poor response to metronidazole in patients with colitis or when metronidazole cannot be given, as in early pregnancy.

Other antibiotics are also effective for $\mathrm{C}$ difficile disease. Oral bacitracin has been given at $80,000 \mathrm{U} /$ day. However, it is expensive, and its use is limited by an unpalatable taste (24). In one study it was less effective than vancomycin (25). Fusidic acid has also been used to treat $\mathrm{C}$ difficile (26); it is not available in the United States. The glycopeptide antibiotic teicoplanin, given $100 \mathrm{mg}$ twice a day for 10 days was shown to be equivalent in efficacy to vancomycin $500 \mathrm{mg}$ qid $(27,28)$. It may soon be available in the United States. Other glycopeptides under investigation include eremomycin (studied in hamsters) and ramoplanin.

Nonantimicrobial therapy: The use of antidiarrheals in PMC is controversial, but there is suggestive evidence that they should be avoided. Agents such as diphenoxylate hydrochloride or loperamide decrease diarrhea, but the decreased transit may lengthen the duration of illness and lead to complications (29).

The bile salt-binding resin cholestyramine has been used; this agent causes constipation and may be helpful in decreasing diarrhea. The rationale for these bile salt-binding agents came from the notion that the resin might also bind toxin, though this has not been supported by laboratory evaluation. In addition, resin binding of antibiotics would decrease their efficacy. Thus, we do not recommend their use in most cases. Clinical response: The diarrhea usually improves in one to four days, with resolution by two weeks. Recurrence of diarrhea occurs in $12 \%$ to $24 \%$ of cases and is difficult to treat as further recurrences become even more likely (see 'Recurrent C difficile').

Treatment when ileus or toxic colon is present: The patient with PMC who has an associated ileus or toxic colon or megacolon presents a therapeutic dilemma because it is difficult to deliver the oral antibiotics to the colon. Therapy should include intravenous metronidazole, which penetrates

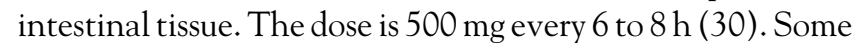
feel that intravenous vancomycin may have no role because failure may occur (31-33). We, however, favour the advice of Fekety and Shah (34), who recommended the use of 
parenteral vancomycin as well as metronidazole. This is such a desperate clinical situation that all measures should be tried to reverse the disease process. Vancomycin can be given by nasogastric tube or rectally as enemas. The senior author has had experience using a colonoscope to decompress a dilated colon, and then placing a decompression tube to relieve distension as well as to deliver vancomycin. On rare occasions, a surgical cecostomy may be necessary to decompress the colon and deliver vancomycin to the colonic lumen. In these critically ill patients, serial clinical evaluation is important to look for signs that urgent surgery may be needed. Mortality from fulminant toxic colitis or perforation is very high.

Indications for surgery: The main indication for surgery is worsening clinical condition despite adequate therapy. Clinical clues are organ failure, peritonitis (suggesting perforation) and progressive colitis. Progressive disease can be documented by abdominal computed tomography scan; a very thick colon wall and the presence of ascites are poor prognostic signs. In one surgical series, patients with a worse prognosis were older, had an ileus, history of recent antibiotics, and ascites or very thick colon wall on computed tomography scan (35).

The procedure of choice is subtotal colectomy because segmental resection of colitis often leads to reoperation to remove remaining diseased bowel (36). The key to avoiding this grim situation is early diagnosis and therapy. The rectal stump should be irrigated postoperatively with vancomycin because $\mathrm{C}$ difficile persists there after surgery.

Recurrent $\mathrm{C}$ difficile: Most patients respond to treatment with resolution of diarrhea, but $20 \%$ of patients relapse; these patients are even more likely to have continued relapses. This is a challenging clinical problem. The pathophysiology is not known; it is likely due to altered fecal flora, allowing continued overgrowth of $\mathrm{C}$ difficile. In one study, fingerprints of $\mathrm{C}$ difficile isolates showed that over half of patients with recurrences had the same strain (37). In other cases, a new strain can cause the recurrence.

There are three basic therapeutic approaches to relapsing $\mathrm{C}$ difficile colitis: antibiotics, binding resins and ecological approaches.

Antibiotics: Most patients need repeated courses of antibiotics, usually metronidazole or vancomycin. The same or an alternate antibiotic is repeated or vancomycin is given in tapered or pulsed doses, or longer (several weeks) courses are given. Pulsing makes the most sense because it allows spores (which are resistant to antibiotics) to germinate and be killed by the antibiotic when it is given again.

Binding resins: While binding resins are reported to bind the toxin, their efficacy has never been proven. They can be nonspecifically constipating. We do not recommend their use, but if given they should be timed in such a way as not to bind the antibiotics, such as cholestyramine or colestipol. Ecological approaches: Ecological approaches are the most sensible because they promote normalization of the fecal flora, which should then inhibit overgrowth of $\mathrm{C}$ difficile (a) Saccharomyces boulardii. We have been treating patients with $S$ boulardii as a part of a research protocol. S boulardii is a non- pathogenic yeast with an unusual optimum growth temperature of $37^{\circ} \mathrm{C}$. The yeast was originally isolated from the lychee fruit in Southeast Asia in the 1920s after observations of folkloric use as an antidiarrheal agent. Animal studies using the hamster model of clindamycin colitis showed a significant decrease in mortality when animals were treated with S boulardii compared with placebo (38). When S boulardii was used to treat relapse in the same animal model, it was also highly efficacious (39). When used as an adjunct to antibiotic therapy in first infections with $\mathrm{C}$ difficile disease, it had no benefit over placebo in recurrent disease. However it was significantly more effective than placebo as an adjunct to antibiotic therapy in the treatment of recurrent $\mathrm{C}$ difficile disease in those who had already had one or more recurrence (40).

It is not known how $S$ boulardii exerts its prophylactic or therapeutic effects. It does have antagonistic properties against several pathogens in vitro and in vivo in animal models. Other mechanisms of action include activation of C difficile toxin or its receptor in vitro (41), stimulation of immunoglobulin A in rat small intestine (42) and normalization of fecal flora. Importantly, it resists the effect of antibiotics. Other advantages include the ease of oral administration and lack of side effects because the yeast is not absorbed.

Nontoxigenic strains of $\mathrm{C}$ difficile: Two cases of $\mathrm{C}$ difficile were successfully treated with oral administration of nontoxogenic strains of $\mathrm{C}$ difficile (43). About one-quarter of $\mathrm{C}$ difficile isolates do not produce toxin and thus do not cause disease. This approach may be associated with a decrease in relapsing PMC, although only a small number of individuals have been treated.

Rectal bacteriotherapy: Rectal bacteriotherapy has been reported to treat relapsing PMC. Specifically, fecal enemas have been given to patients, using rectal infusion of homologus feces donated from healthy donors, such as relatives (44). However, this is not advisable because it is impossible to assure the safety of homologus feces and other pathogens may be introduced inadvertently.

Somewhat more aesthetically appealing, however, is the use of rectal installation of mixtures of anaerobes that may result in the clearing of $\mathrm{C}$ difficile. Five patients with relapsing PMC were treated with rectal instillation of 10 different facultatively anaerobic and aerobic bacteria, with prompt clearing of $C$ difficile and its toxin from the stool (45). An additional patient in this study was treated with an enema of fresh feces from a healthy relative. The study showed that Bacteriodes species had been absent during the patient's illness and was present after recovery, suggesting that colonization with Bacteriodes species appears to be especially important in maintaining normal bowel function and strengthening the resistance to gastrointestinal infections. The ability of the Bacteriodes species to aid in restoration of intestinal homeostasis may be related to its production of beta-lactamase, as previously described.

Lactobacillus GG: Lactobacillus GG is a species with unusual characteristics. It is resistant to gastric acid and to bile, and 
survives in the human gastrointestinal tract for four to seven days. In a published letter (46), five patients with relapsing $\mathrm{C}$ difficile (two to five prior relapses) had no further relapses after oral therapy with Lactobacillus GG. A recent presentation did not show any efficacy of Lactobacillus GG in a patient with recurrent $C$ difficile disease (47).

\section{PROGNOSIS}

Recent evaluation of prognostic criteria revealed a worse prognosis with a low albumin (less than $25 \mathrm{~g} / \mathrm{L}$ ), a fall in albumin greater than $11 \mathrm{~g} / \mathrm{L}$, more than three antibiotics and persistent toxin in the stools seven days or longer after therapy (48). There was no correlation with sex, age, length of hospital stay, past illness or recurrent $\mathrm{C}$ difficile infection.

\section{REFERENCES}

1. McFarland LV, Mulligan ME, Kwok RY, Stamm WE. Nosocomial acquisition of Clostridium difficile infection. $\mathrm{N}$ Engl J Med 1989;320:204-10.

2. Van der Waaij D, Berghuis-de Vries JM, Lekkerkerk Lekkerkerk-v. Colonization resistance of the digestive tract in conventional and antibiotic treated mice. J Hyg (Lond) 1971;69:405-11.

3. Bliss DZ, Johnson S, Savik K, Clabots CR, Willasrd K, Gerding DN. Acquisition of Clostridium difficile and Clostridium difficile-associated diarrhea in hospitalized patient receiving tube feeding. Ann Intern Med 1998;129:1012-9.

4. Borriello SP. Pathogenesis of Clostridium difficile infection. J Antimicrob Chemother 1998;41(Suppl C):13-9

5. Riegler M, Sedivy R, Pouthoulakis C, et al. Clostridium difficile toxin B is more potent than toxin $\mathrm{A}$ in damaging human colonic epithelium in vitro. J Clin Invest 1995;95:2004-11.

6. Just I, Selzer J, Wilm M, von Eichel-Streiber C, Mann M, Aktories K. Glucosylation of Rho proteins by Clostridium difficile toxin B. Nature 1995;375:500-3.

7. Prospective study of Clostridium difficile intestinal colonization and disease following single dose antibiotic prophylaxis in surgery. Antimicrob Agents Chemother 1991;35:208-10

8. Manabe YC, Vinetz JM, Moore RD, Merz C, Charache P, Bartlett JG. Clostridium difficile colitis: an efficient clinical approach to diagnosis. Ann Intern Med 1995;123:835-40.

9. Katz DA, Bates DW, Rittenber E, et al. Predicting Clostridium difficile stool cytotoxin results in hospitalized patients with diarrhea. J Gen Intern Med 1997;12:57-62.

10. Brazier JS. The diagnosis of Clostridium difficile-associated disease. J Antimicrob Chemother 1998;41:29-40.

11. Lashner BA, Todorczuk J, Sahm DF, Hanauer SB. Clostridium difficile culture-positive toxin-negative diarrhea. Am J Clin Gastroenterol 1986;81:940-3.

12. Yolken Rh, Whitcomb LS, Marien G, et al. Enzyme immunoassay for the detection of Clostridium difficile antigen. J Infect Dis $1981 ; 144: 378$.

13. Merz CS, Cramer C, Forman M, et al. Comparison of four commercially available rapid immunoassays with cytotoxin assay for detection of Clostridium difficile toxin(s) from stool specimens. J Clin Microbiol 1994;32:1142-7.

14. Shue V, Green GA, Monteil H. Comparison of ToxA test with cytotoxicity assay and culture for the detection of Clostridium difficile associated diarrhoeal disease. J Med Microbiol 1994;41:316-8.

15. Tsimidis K, Simor AE. Evaluation of an enzyme immunoassay for detection of Clostridium difficile toxin A. Eur J Clin Microbiol Infect Dis 1992;11:363-4.

16. De Girolami PC, Hanff PA, Eichelberger K, et al. Multicenter evaluation of a new enzyme immunoassay for detection of Clostridium difficile enterotoxin. J Clin Microbiol 1992;30:1085-8.

17. Lyerly DM, Wilkins TD. Commercial latex test for Clostridium difficile toxin A does not detect toxin A. J Clin Microbiol 1986;23:622-3.

18. Green GA, Riot B, Monteil H. Evaluation of an oligonucleotide probe and an immunologic test for direct detection of toxigenic Clostridium difficile in stool samples. Eur J Clin Microbiol Infect Dis 1994;13:576-81.

19. Alonzo R, Munoz C, Pelaez T, et al. Rapid detection of toxigenic
Clostridium difficile strains by a nested PCR of the toxin B gene. Clin Microbiol Infect 1997;3:145-7.

20. Fekety R, Silva J, Kauffman C, Buggy B, Derry HG. Treatment of antibiotic-associated Clostridium difficile colitis with oral vancomycin: comparison of two dosage regimens. Am J Med 1989:86:15-9.

21. Tedesco F, Markham R, Gurwith M, Christie D, Bartlett JG. Oral vancomycin for antibotic-associated pseudomembranous colitis. Lancet 1978;i:226-8.

22. Silva J Jr, Batts DH, Fekety R, Plouffe JF, Rifkin GD, Baird L. Treatment of Clostridium difficile colitis and diarrhea with vancomycin. Am J Med 1981;71:815-21.

23. Teasley, DG, Olson MM, Gebhad RL, et al. Protective randomized trial of metronidazole versus vancomycin for Clostridium difficile associated diarrhea and colitis. Lancet 1983;ii:1043-6.

24. Young GP, Ward PB, Bayley N, et al. Antibiotic-associated colitis due to Clostridium difficile: double-blind comparison of vancomycin with bacitracin. Gastroenterology 1985;89:1038-45.

25. Dudley MN, McLaughlin C, Carrington G, et al. Oral bacitracin vs. vancomycin therapy for Clostridium difficile-induced diarrhea: a randomized double-blind trial. Arch Intern Med 1986;146:1101-4.

26. Cronberg S, Castor B, Thoren A. Fusidic acid for the treatment antibiotic associated colitis induced by Clostridium difficile. Infection 1984;12:276-9.

27. DeLalla F, Nicolin R, Rinaldi E, et al. Prospective study of oral teicoplanin versus oral vancomycin for therapy of pseudomembranous colitis and Clostridium difficile-associated diarrhea. Antimicrob Agents Chemother 1992;362:2192-6.

28. DeLalla F, Privitera G, Rinaldi E, Ortisi G, Santoro D, Rizzardini. Treatment of Clostridium difficile-associated disease with teicoplanin. Antimicrob Agents Chemother 1989;33:1125-7.

29. Church JM, Fazio VW. A role for colonic stasis in the pathogenesis of disease related to Clostridium difficile. Dis Colon Rectum 1986;29:804-9.

30. Kleinfeld DI, Sharpe RJ, Donta ST. Parenteral therapy for antibiotic-associated pseudomembranous colitis. J Infect Dis 1988;157:389. (Lett)

31. Oliva SL, Guglielmo BJ, Jacabs R, Pons VG. Failure of intravenous vancomycin and intravenous metronidazole to prevent or treat antibiotic-associated pseudomembranous colitis. J Infect Dis 1989;159:1154-5.

32. Bolton RP, Culshaw MA. Faecal metronidazole concentrations during oral and intravenous therapy for antibiotic associated colitis due to Clostridium difficile. Gut 1986;27:1169-72.

33. Guzman R, Kirkpatrick, Forward K, Lim F. Failure of parenteral metronidazole in the treatment of pseudomembranous colitis. J Infect Dis $1988 ; 158: 1146-7$.

34. Fekety R, Shah AB. Diagnosis and treatment of Clostridium difficile colitis. JAMA 1993;269:71-5.

35. Prendergast TM, Marini CP, D'Angelo AS, Sher ME, Cohen JR. Surgical patients with pseudomembranous colitis: factors affecting progress. Surgery 1994;116:768-74.

36. Lipsett PA, Samanatarau OK, Tam ML, Bartlett JG, Lillemoe KD. Pseudomembranous colitis: a surgical disease? Surgery 1994;116:491-6.

37. Wilcox MH, Fawley WN, Settle CD, Davidson A. Recurrence of symptoms in Clostridium difficile infection - relapse or reinfection? J Hosp Infect 1998;38:93-100.

38. Toothaker RD, Elmer GW. Prevention of clindamycin-induced mortality in hamsters by Saccharomyces boulardii. Antimicrob Agents Chemother 1984;26:552-6.

39. Elmer GW, McFarland LV. Suppression by Saccharomyces boulardii of toxigenic Clostridium difficile overgrowth after vancomycin treatment in hamsters. Antimicrob Agents Chemother 1987;31:129-31.

40. McFarland LV, Surawicz CM, Greenberg RN, et al. A randomized placebo-controlled trial of Saccharomyces boulardii in combination with standard antibiotics for Clostridium difficile disease. JAMA 1994:271:1913-8.

41. Pothoulakis C, Kelly CP, Joshi MA, et al. Saccharomyces boulardii inhibits Clostridium difficile toxin A binding and enterotoxicity in rat ileum. Gastroenterology 1993;104:1108-15.

42. Butts JP, Bernasconi P, Vaerman JP, Dive C. Stimulation of secretory IgA and secretory component of immunoglobulins in small intestine of rats treated with Saccharomyces boulardii. Dig Dis Sci 1990;35:251-6. 
43. Seal DV, Borriello SP, Barclay F, Welch A, Piper M, Bonnycastle M. Treatment of relapsing Clostridium difficile diarrhoea by administration of non-toxigenic strain. Eur J Clin Microbiol 1987;6:51-3.

44. Schwan A, Sjolin S, Trottestam U, et al. Relapsing C. difficile enterocolitis cured by rectal infusion of normal feces. Scand J Infect Dis 1984;16:211-5.

45. Tvede, Rask-Madsen J. Bacteriotherapy for chronic relapsing Clostridium difficile diarrhea in six patients. Lancet 1989;i:1156-60.

46. Gorbach SL, Chang TW, Goldin B. Successful treatment of relapsing
Clostridium difficile colitis with Lactobacillus GG. Lancet 1987;ii:1519. (Lett)

47. Pochapin MB, Oltikar A, Pringle-Smith R, Schreiber C. A Prospective randomized placebo-controlled trial of Lactobacillus GG in combination with standard antibiotics for the treatment of Clostridium difficile infection. Am J Gastroenterol 1998;93:1697.

48. Ramaswamy R, Grover H, Corpuz M, Daniels P, Pitchoumoni CS. Prognostic criteria in Clostridium difficile colitis. Am J Gastroenterol 1996;91:460-4. 


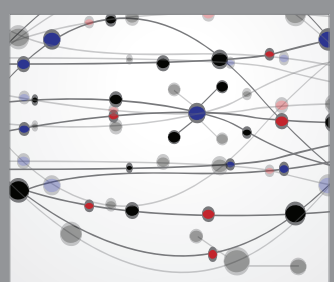

The Scientific World Journal
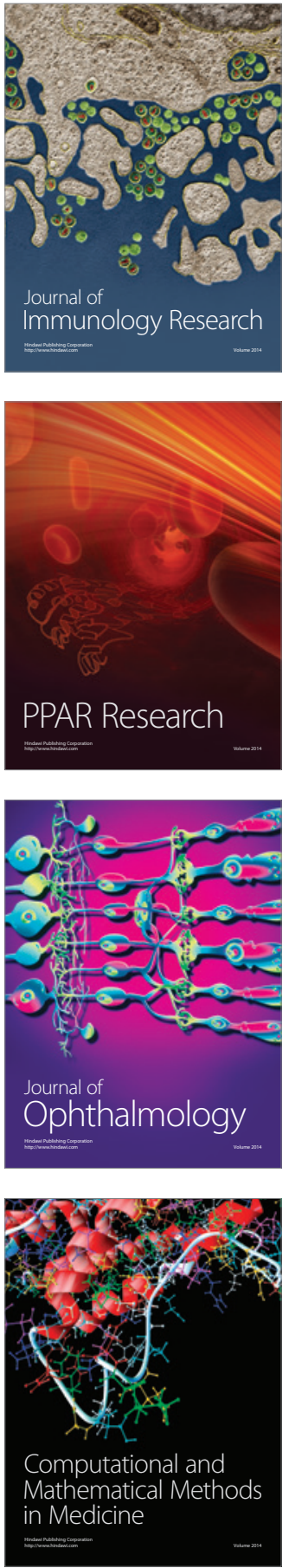

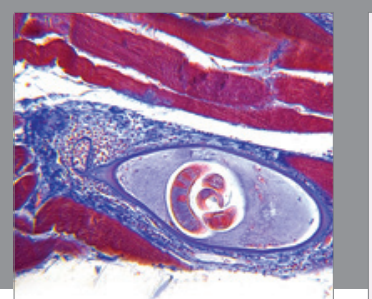

Gastroenterology Research and Practice

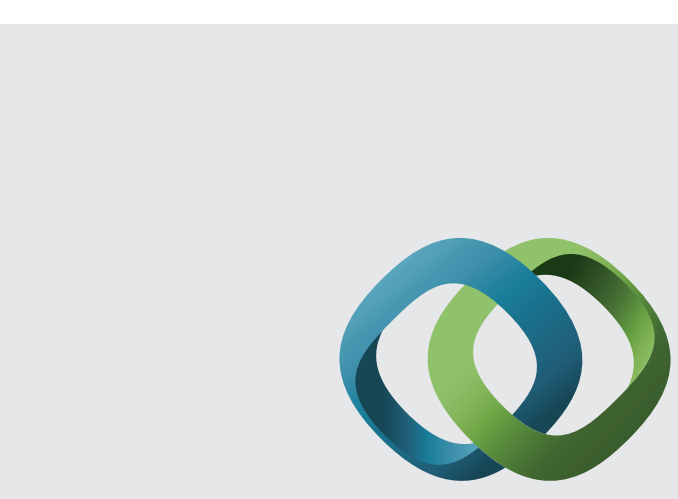

\section{Hindawi}

Submit your manuscripts at

http://www.hindawi.com
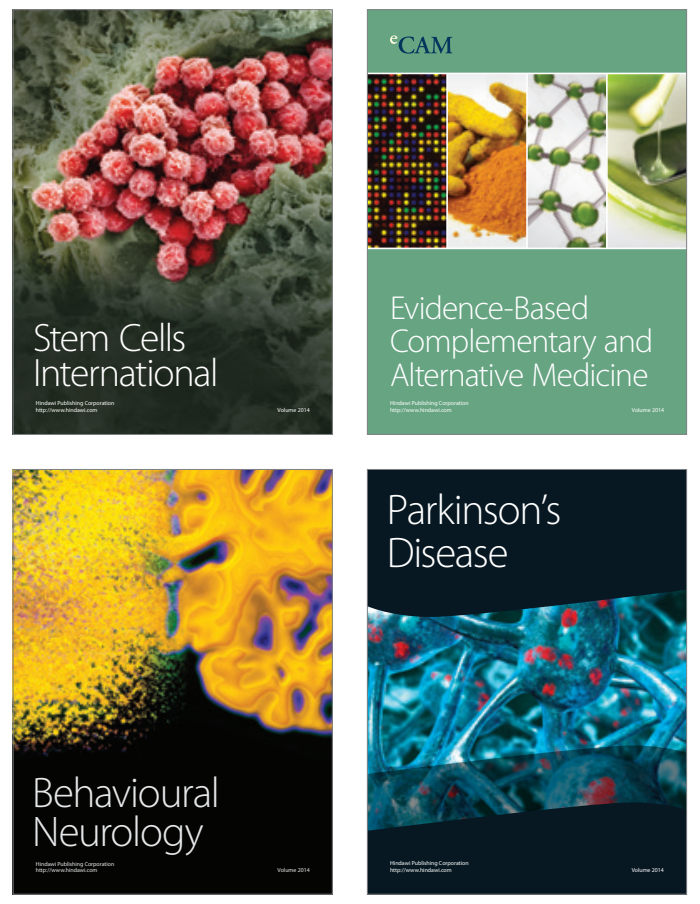
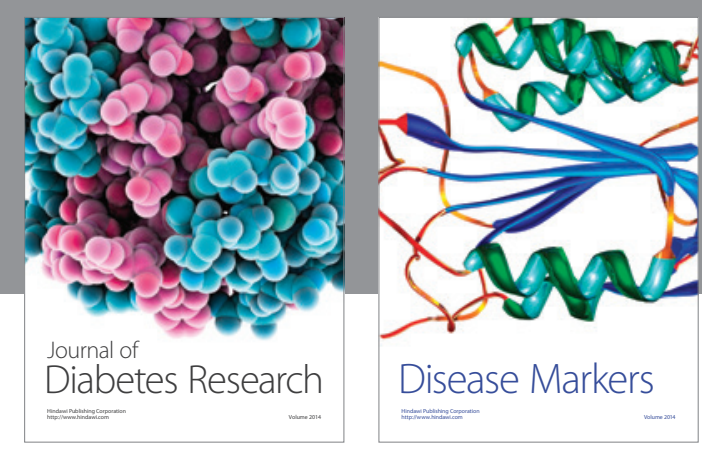

Disease Markers
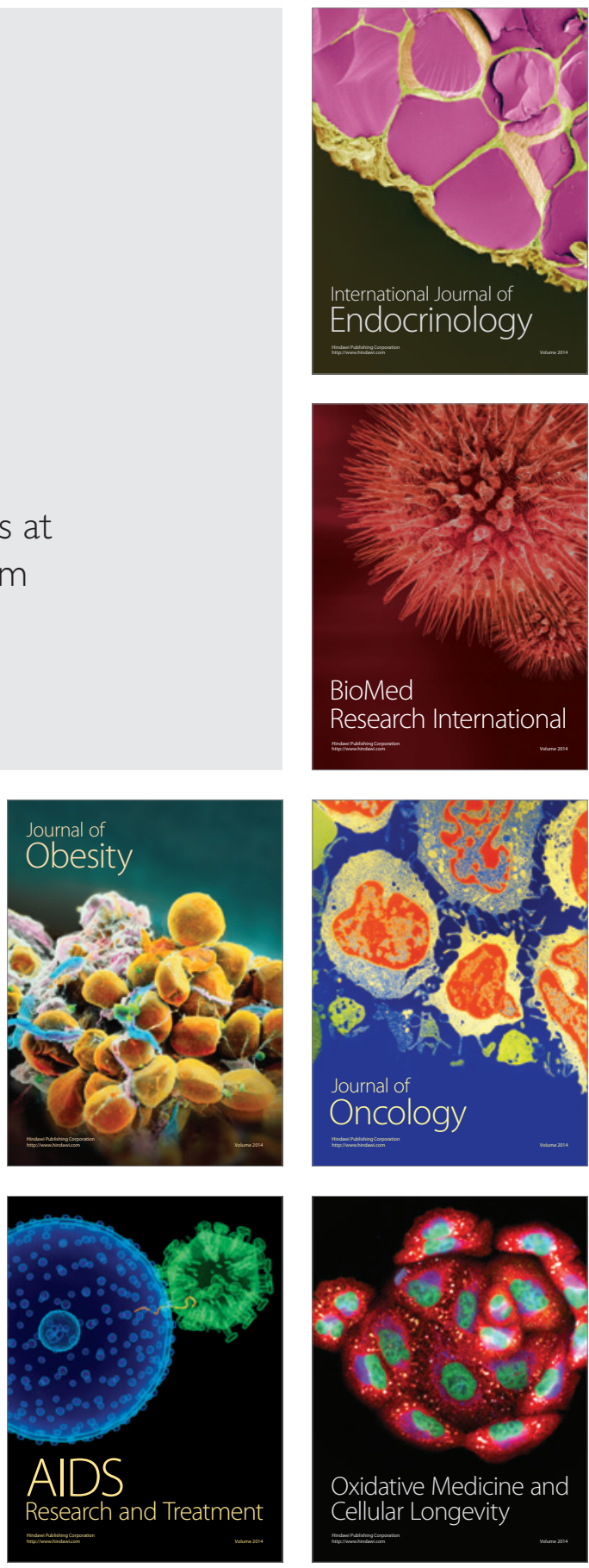